\title{
IMPACT OF DEFICIT IRRIGATION ON SORGHUM PHYSICAL AND CHEMICAL PROPERTIES AND ETHANOL YIELD
}

\author{
L. Liu, A. Maier, N. Klocke, S. Yan, D. Rogers, T. Tesso, D. Wang
}

\begin{abstract}
The objective of this research was to study the effect of irrigation levels (five levels from 304.8 to $76.2 \mathrm{~mm}$ water) on the physical and chemical properties and ethanol fermentation performance of sorghum. Ten sorghum samples grown under semi-arid climatic conditions were harvested in 2011 from the Kansas State University Southwest ResearchExtension Center near Garden City, Kansas, and evaluated. Irrigation had a significant effect on the physical properties, chemical composition, ethanol yield, and fermentation efficiency of sorghum. Sorghum kernel hardness increased and test weight decreased as the irrigation level decreased. Starch contents of sorghum samples grown under a low irrigation level were approximately 7\% less than those grown under a high irrigation level. Protein contents ranged from 9.84\% to $14.91 \%$ and increased as irrigation level decreased. Starch pasting temperature increased significantly, and starch peak pasting viscosity and setback viscosity decreased as the irrigation level decreased. Free amino nitrogen (FAN) increased significantly as irrigation decreased. Ethanol fermentation efficiency ranged from $90.6 \%$ to $91.9 \%$ and correlated positively with FAN during the first $30 \mathrm{~h}$ of fermentation $\left(R^{2}=0.926\right)$. Deficit irrigation level had a negative impact on ethanol yield. The sorghum with low irrigation yielded about $8.9 \%$ less ethanol (434.52 $\mathrm{mL}$ ethanol per $\mathrm{kg}$ sorghum) than samples with higher irrigation (473.32 mL ethanol per $\mathrm{kg}$ sorghum). Residual starch contents in the distillers dried grains with solubles was less than $1 \%$ and ranged from $0.70 \%$ to $0.84 \%$.
\end{abstract}

Keywords. Composition, Ethanol yield, Irrigation, Physical properties, Sorghum.

I rrigation plays a major role in food production and food security worldwide. Irrigated agriculture produces nearly $40 \%$ of the world's food and agricultural commodities on $17 \%$ of the available agricultural land (Kirda, 2002). Irrigated agriculture is the primary user of water resources globally and consumes $70 \%$ to $80 \%$ of total diverted water in the arid and semi-arid zones (Fereres and Soriano, 2007). Irrigated agriculture used more than $70 \%$ of the water withdrawn from Earth's rivers (FAO, 2003). Crop production is highly dependent on water availability, and any shortage of water has a significant impact on the final yields of crops (Kirda, 2002; Tognetti et al., 2006; Quiroga et al., 2011); however, water is a finite resource for which competition is increasing among the agricultural, industrial, and domestic sectors.

With reduced water resources available for agriculture,

Submitted for review in February 2013 as manuscript number FPE 10153; approved for publication by the Food \& Process Engineering Institute of ASABE in July 2013.

The authors are Liman Liu, Research Assistant, Department of Biological and Agricultural Engineering, Anne Maier, Undergraduate Student, Department of Chemical Engineering, and Norman L. Klocke, ASABE Member, Professor, Department of Biological and Agricultural Engineering, Kansas State University, Manhattan, Kansas; Shuping Yan, Laboratory Manager, C. W. Brabender Instruments, Inc., South Hackensack, New Jersey; Danny H. Rogers, ASABE Member, Professor, Department of Biological and Agricultural Engineering, Tesfaye Tesso, Associate Professor, Department of Agronomy, and Donghai Wang, ASABE Member, Professor, Department of Biological and Agricultural Engineering, Kansas State University, Manhattan, Kansas. Corresponding author: Donghai Wang, 150 Seaton Hall, Kansas State University, Manhattan, KS 66506; phone: 785-532-2919; e-mail address: dwang@ksu.edu. scientists and engineers have developed innovative technologies such as deficit irrigation programs aimed at increasing the efficient use of irrigation water (Kirda, 2002; Tognetti et al., 2006; Fereres and Soriano, 2007). Water deficits during a specific crop development period significantly affect crop yield; therefore, the yield response to water stress has been studied extensively. Previous research has reported that grain yields decrease as irrigation level decreases (Kirda et al., 2005; Fereres and Soriano, 2007; Ayana, 2011). Pandey et al. (2000) studied the effects of deficit irrigation on maize and found that grain yield reduction was proportional to the duration of deficit irrigation. Because corn is an important irrigated crop, many years of field research have been conducted on corn to study the relationship between irrigation and yields. Some field research on corn has indicated that grain yields do not decrease at the same rate as irrigation. Klocke et al. (2007) studied the relationship between corn yield and irrigation from 1986 to 1998 in west central Nebraska and found that $90 \%$ of full irrigation grain yields could be gained by applying only $47 \%$ of full irrigation. Klocke et al. (2011) conducted a field study of fully irrigated to deficit-irrigated corn grain in 2005 to 2009 in southwest Kansas and reported that yield variability increased as irrigation decreased, illustrating a greater income risk with less irrigation.

As water resources continue to decline, deficit irrigation is becoming an important strategy for minimizing agricultural water use. In addition to crop yield, limited or deficit irrigation also may significantly affect grain quality and end uses; however, little attention has been paid to effects 
on grain quality and end-use quality, such as in the area of ethanol yield.

Sorghum is the fifth largest crop produced worldwide, and the U.S. is one of its largest producers. Of U.S. sorghum production, 50\% comes from Kansas. Sorghum is mostly used in livestock feed and fuel ethanol production, with only a small portion used in production of food for human consumption; because it is safe for people with celiac disease, sorghum has been used to develop gluten-free products (Ciacci et al., 2007). The use of sorghum in ethanol production has increased in recent years; $30 \%$ to $35 \%$ of the total crop was used for ethanol production in 2011 (USDA, 2011). Previous studies have shown that the amylose-to-amylopectin ratio, starch content, protein digestibility, protein content, free amino nitrogen, formation of amylose-lipid complex, and particle size of ground grain meal have significant effects on ethanol yield and fermentation efficiency (Wu, 1989; Zhan et al., 2003; Wu et al., 2006, 2007, 2008; Pérez-Carrillo and Serna-Saldívar, 2007; Yan et al., 2009, 2010, 2011). Therefore, sorghum grain qualities are important and greatly affect end-use product qualities.

Scarce research has been conducted in recent years on grain sorghum regarding the effect of irrigation on its grain quality and ethanol yield (Wu et al., 2008; Miller and Ottman, 2010). The objective of this research was to study the effect of irrigation levels (five levels from 304.8 to $76.2 \mathrm{~mm}$ water) on the physical and chemical properties and ethanol fermentation performance of sorghum.

\section{Materials And Methods \\ MATERIALS}

Ten sorghum samples with five irrigation levels (five levels from 304.8 to $76.2 \mathrm{~mm}$ water) were harvested from the Kansas State University Southwest Research-Extension Center near Garden City, Kansas, in 2011. All samples were hand-picked to remove large foreign materials. For ethanol fermentation, the cleaned samples were ground into fine flour by passing through a $0.5 \mathrm{~mm}$ screen on a UDY Cyclone Mill (UDY Corp., Fort Collins, Colo.). These ten samples were evaluated on physical and chemical properties and ethanol fermentation performance.

\section{Climate, Cropping System, and Irrigation}

Sorghum was grown in a five-year rotation of corn-cornwheat-sorghum-sunflower during 2005 to 2011. The climate is semi-arid with long-term average annual precipitation of $477 \mathrm{~mm}$, mean summer growing season daytime high temperature of $29^{\circ} \mathrm{C}$ (30-year average, May through August), open-pan evaporation (April through September) of $1810 \mathrm{~mm}$, and a frost-free period of 170 days. The average annual precipitation was $246 \mathrm{~mm}$, around half of the long-term average. The five irrigation levels (304.8, 228.6, $177.8,127.0$, and $76.2 \mathrm{~mm}$ water) were achieved by increasing the time between irrigation events, which were intended to simulate differences in irrigation system capacity to deliver water using a constant irrigation amount per event. The irrigation treatment protocol was designed to include operational constraints of commercial center-pivot irrigation systems in the Great Plains region, where systempumping capacities limit the frequency of irrigation events. Irrigation treatments were replicated four times with random locations in each replication. Cultural practices, including no-till planting techniques, fertilizer applications, and weed control, were the same across irrigation treatments and followed the requirements of no-till management.

\section{Physical Properties of Sorghum Kernels}

Sorghum single-kernel hardness, weight, and size were characterized with the single-kernel characterization system (SKCS 4100, Perten Instruments, Huddinge, Sweden) according to Bean et al. (2006). Kernel density was determined with an air-comparison pycnometer (model MVP-1, Quantachrome Corp., Syosset, N.Y.), as described by Pomeranz et al. (1984). The 1000-kernel weights were obtained from the kernel weight of 1000 whole, sound kernels. Sorghum test weight was determined by AACC Approved Method 55-10 (AACC, 2000).

Microstructures of sorghum endosperm were examined using a Hitachi S-3500N scanning electron microscope (SEM) with an S-6542 absorbed electron detector (Hitachinaka, Ibaraki, Japan). Samples were coated with $4 \mathrm{~nm}$ of a $60 \%$ gold and $40 \%$ palladium mixture in a Denton vacuum chamber (Desk II, Moorestown, N.J.) prior to SEM examination. Images were taken from enlarged floury endosperm with $500 \times$ magnification.

\section{Chemical Composition of Sorghum}

Total starch was analyzed using AACC Approved Method 76-13 (AACC, 2000). Crude protein, fat, and ash were analyzed using AOAC Approved Methods 990.03, 920.39, and 942.05, respectively (AOAC, 1999), and crude fiber was analyzed with the A200 filter bug technique (AOCS, 2006). Free amino nitrogen (FAN) was determined using the European Brewery Convention method (EBC, 1987) with modification. Around $150 \mathrm{mg}$ sorghum flour was mixed with $1.5 \mathrm{~mL}$ of deionized distilled water in a $2.5 \mathrm{~mL}$ microcentrifuge tube, vortexed five times in $10 \mathrm{~min}$, and then centrifuged at $12,000 \mathrm{rpm}$ for $20 \mathrm{~min}$. An aliquot of $1.0 \mathrm{~mL}$ supernatant was diluted with $9.0 \mathrm{~mL}$ distilled water, and then was ready for FAN analysis.

\section{Thermal Properties}

Thermal properties were analyzed using TA DSC Q200 V24.4 instrument (TA Instruments, New Castle, Del.). Sorghum flour samples with different irrigation levels were weighed accurately (approx. 5 to $8 \mathrm{mg}$ ) into stainless steel pans using a microbalance. Deionized distilled water was added carefully with a micropipette into the sample pan. The weight ratio of water to dry flour was $2: 1$. The pans were sealed and allowed to rest overnight at room temperature. An empty sealed pan was used as a reference. Samples were characterized in an inert environment using nitrogen with a gas flow rate of $50 \mathrm{~mL} \mathrm{~min}^{-1}$ and were heated from $0^{\circ} \mathrm{C}$ to $140^{\circ} \mathrm{C}$ at heating rates of $10^{\circ} \mathrm{C} \mathrm{min}^{-1}$. Enthalpies are reported on a dry flour weight basis. Onset temperature 
$\left(T_{o}\right)$, peak temperature $\left(T_{p}\right)$, conclusion temperature $\left(T_{c}\right)$, and enthalpy of gelatinization $\left(\Delta H_{g e l}\right)$ were calculated.

\section{Pasting Properties}

A Brabender Micro Visco-Amylo-Graph-U (MVAG-U, model 803222, Brabender GmbH \& Co., Duisburg, Germany) was used to test pasting properties of sorghum flour. Ten grams of flour (14\% moisture content) and $105 \mathrm{~g}$ distilled water were mixed in the testing bowl at room temperature; the slurry was heated from $30^{\circ} \mathrm{C}$ to $95^{\circ} \mathrm{C}$ at a heating rate of $8.0^{\circ} \mathrm{C} \mathrm{min}^{-1}$; then the hot paste was held at $95^{\circ} \mathrm{C}$ for $5 \mathrm{~min}$, cooled to $30^{\circ} \mathrm{C}$ at a cooling rate of $8.0^{\circ} \mathrm{C} \mathrm{min}^{-1}$, and held at $30^{\circ} \mathrm{C}$ for $1 \mathrm{~min}$. The total process took $22 \mathrm{~min}$ and $16 \mathrm{~s}$. The test speed of the stirrer was $300 \mathrm{rpm}$, and the measurement sensitivity range was $250 \mathrm{cmg}$.

\section{ETHANOL FERMENTATION}

Whole sorghum flour (30 g, dry mass) was weighed into a clean $250 \mathrm{~mL}$ Erlenmeyer flask and mixed with $100 \mathrm{~mL}$ of preheated (around $60^{\circ} \mathrm{C}$ to $70^{\circ} \mathrm{C}$ ) enzyme solution containing $0.1 \mathrm{~g} \mathrm{KH}_{2} \mathrm{PO}_{4}$ and $20 \mu \mathrm{L}$ Liquozyme (alphaamylase, Novozymes, Franklinton, N.C.). Samples were evenly wetted and thoroughly suspended. Flasks were transferred to a $70^{\circ} \mathrm{C}$ rotary water-bath shaker operating at $\sim 180 \mathrm{rpm}$. The temperature of the water bath was raised to $90^{\circ} \mathrm{C}$ for about $30 \mathrm{~min}$, and then lowered to $86^{\circ} \mathrm{C}$ and maintained for $60 \mathrm{~min}$. Flasks were removed from the water-bath shaker, and material sticking on the inner surface of the flasks was pushed back into the mashes with a spatula. The inner surface and spatula were rinsed using 3 to 5 $\mathrm{mL}$ distilled water. After the mashes cooled to room temperature (approx. $25^{\circ} \mathrm{C}$ to $30^{\circ} \mathrm{C}$ ), the $\mathrm{pH}$ of the mashes was adjusted to around 4.2 with $2 \mathrm{~N} \mathrm{HCl}$.

Before the simultaneous saccharification and fermentation (SSF) process, the dry yeast was activated by adding $1.0 \mathrm{~g}$ of active dry yeast (Red Star, Lesaffre Yeast Corp., Milwaukee, Wisc.) into $19 \mathrm{~mL}$ of preculture broth (containing $20 \mathrm{~g}$ glucose, $5.0 \mathrm{~g}$ peptone, $3.0 \mathrm{~g}$ yeast extracts, $1.0 \mathrm{~g}$ $\mathrm{KH}_{2} \mathrm{PO}_{4}$, and $0.5 \mathrm{~g} \mathrm{MgSO}_{4} \cdot 7 \mathrm{H}_{2} \mathrm{O}$ per L) and incubated in an incubator at $38^{\circ} \mathrm{C}$ for $30 \mathrm{~min}$ at $200 \mathrm{rpm}$.

An aliquot of $1.0 \mathrm{~mL}$ of activated yeast culture, $100 \mu \mathrm{L}$ of Spirizyme (Glucoamylase, Novozymes, Franklinton, N.C.), and $0.30 \mathrm{~g}$ of yeast extract were added into each flask. Flasks were sealed with an S-airlock filled with mineral oil. Fermentation was conducted at $30^{\circ} \mathrm{C}$ in an incubator shaker operating at $150 \mathrm{rpm}$ for $72 \mathrm{~h}$. The fermentation was monitored by measuring weight loss due to evolution of $\mathrm{CO}_{2}$ during fermentation $\left(\mathrm{C}_{6} \mathrm{H}_{12} \mathrm{O}_{6} \rightarrow 2 \mathrm{C}_{2} \mathrm{H}_{6} \mathrm{O}+2 \mathrm{CO}_{2}\right.$ $\uparrow)$ at $4,8,18,24,32,44,56$, and $72 \mathrm{~h}$ of fermentation.
After $72 \mathrm{~h}$ of fermentation, the finished mash was transferred to a $500 \mathrm{~mL}$ distillation flask. The Erlenmeyer flask was washed with $100 \mathrm{~mL}$ of distilled water. Two drops of antifoam agent were added to the distillation flask before the flask was placed on a heating unit to prevent foaming during distillation. The distillates were collected into a 100 $\mathrm{mL}$ volumetric flask immersed in ice water. When the distillates in the volumetric flask approached the $100 \mathrm{~mL}$ mark ( $\sim 99 \mathrm{~mL})$, the volumetric flask was removed from the distillation unit. The distillates in the volumetric flask were equilibrated for a few hours in a $25^{\circ} \mathrm{C}$ water bath. The ethanol concentration was determined by HPLC following the method described by Wu et al. (2006). Fermentation efficiencies were calculated as the actual ethanol yield divided by the theoretical ethanol yield. The theoretical ethanol yield was determined using the total starch contents in the samples, assuming $0.5672 \mathrm{~g}$ ethanol from $1 \mathrm{~g}$ of starch (Thomas et al., 1996).

\section{Statistical ANALYSIS}

All experiments were conducted at least in duplicate. Results are presented as averages of replications and were subjected to one-way analysis of variance (ANOVA). Pearson correlation coefficients for the relationships between all properties also were calculated using Minitab (ver. 15, Minitab, Inc., State College, Pa.).

\section{RESULTS AND DISCUSSION \\ PHYSICAL PROPERTIES AND CHEMICAL COMPOSITION}

Weights of 1000 sorghum kernels ranged from 23.3 to $26.0 \mathrm{~g}$ and correlated with sorghum single-kernel weight tested by SKCS (table 1). Sorghum single-kernel diameter ranged from 2.05 to $2.18 \mathrm{~mm}$ (table 1 ). No significant differences were found for kernel weight and kernel diameter among all sorghum samples under different irrigation levels. This result may be due to the drought-tolerant sorghum grain; in other words, the irrigation level did not influence sorghum kernel weight and size as much as other cereal kernels. Previous results on maize kernels from our lab showed that kernel weight increased as irrigation level increased. Weightman et al. (2008) studied winter wheat kernels grown in 2002 and 2003 and found that both mean kernel weight and diameter were decreased significantly by drought in 2002, but not in 2003. Sorghum kernels from low irrigation levels had a significantly higher hardness index than those from the high irrigation level (table 1). Grain grown under drought conditions would have higher

Table 1. Physical properties, chemical composition, ethanol yield, and fermentation efficiency of sorghum samples. ${ }^{\text {[a] }}$

\begin{tabular}{|c|c|c|c|c|c|c|c|c|c|c|}
\hline $\begin{array}{c}\text { Irrigation } \\
\text { Level } \\
(1=\text { High, } \\
5=\text { Low }) \\
\end{array}$ & $\begin{array}{c}1000 \\
\text { Kernel } \\
\text { Weight } \\
(\mathrm{g}) \\
\end{array}$ & $\begin{array}{c}\text { Kernel } \\
\text { Hardness } \\
\text { Index }\end{array}$ & $\begin{array}{c}\text { Single } \\
\text { Kernel } \\
\text { Weight } \\
\text { (mg) }\end{array}$ & $\begin{array}{c}\text { Kernel } \\
\text { Diameter } \\
(\mathrm{mm})\end{array}$ & $\begin{array}{c}\text { Test } \\
\text { Weight } \\
\left(\mathrm{g} \mathrm{cm}^{-3}\right)\end{array}$ & $\begin{array}{c}\text { Total } \\
\text { Starch } \\
\text { (\% d.b.) }\end{array}$ & $\begin{array}{l}\text { Crude } \\
\text { Protein } \\
\text { (\% d.b.) }\end{array}$ & $\begin{array}{c}\text { FAN } \\
\left(\mathrm{mg} \mathrm{L}^{-1}\right)\end{array}$ & $\begin{array}{c}\text { Ethanol } \\
\text { Yield } \\
\text { (mL ethanol/ } \\
\text { kg sorghum) }\end{array}$ & $\begin{array}{c}\text { Fermentation } \\
\text { Efficiency } \\
\text { at } 72 \mathrm{~h} \\
(\%)\end{array}$ \\
\hline 1 & $24.05 \mathrm{a}$ & $71.82 \mathrm{~b}$ & $23.73 \mathrm{a}$ & $2.09 \mathrm{a}$ & $0.77 \mathrm{a}$ & $72.45 \mathrm{a}$ & $10.14 \mathrm{~b}$ & $41.11 \mathrm{~b}$ & $473.32 \mathrm{a}$ & $90.6 \mathrm{a}$ \\
\hline 2 & $23.25 \mathrm{a}$ & $78.26 \mathrm{~b}$ & $23.04 \mathrm{a}$ & $2.05 \mathrm{a}$ & $0.77 \mathrm{a}$ & $70.95 \mathrm{a}$ & $11.29 \mathrm{~b}$ & $42.05 \mathrm{~b}$ & $466.88 \mathrm{a}$ & $90.9 \mathrm{a}$ \\
\hline 3 & $24.40 \mathrm{a}$ & $86.16 \mathrm{a}$ & $24.79 \mathrm{a}$ & $2.18 \mathrm{a}$ & $0.77 \mathrm{a}$ & $70.15 \mathrm{a}$ & $12.38 \mathrm{~b}$ & $45.64 \mathrm{~b}$ & $460.76 \mathrm{ab}$ & $91.2 \mathrm{a}$ \\
\hline 4 & $24.05 \mathrm{a}$ & $84.77 \mathrm{a}$ & $23.58 \mathrm{a}$ & $2.11 \mathrm{a}$ & $0.74 \mathrm{~b}$ & $66.90 \mathrm{~b}$ & $13.85 \mathrm{a}$ & $52.65 \mathrm{a}$ & $442.36 \mathrm{~b}$ & $91.4 \mathrm{a}$ \\
\hline 5 & $24.00 \mathrm{a}$ & $84.59 \mathrm{a}$ & $23.72 \mathrm{a}$ & $2.16 \mathrm{a}$ & $0.74 \mathrm{~b}$ & $65.45 \mathrm{~b}$ & $14.86 \mathrm{a}$ & $54.75 \mathrm{a}$ & $434.52 \mathrm{~b}$ & $91.4 \mathrm{a}$ \\
\hline
\end{tabular}

Means in the same column followed by different letters are significantly different $(\mathrm{p} \leq 0.05)$. In the same column, means followed by "a" are significantly higher than means followed by "b," and means followed by "ab" have no significant differences with means followed by "a" or "b." 
kernel hardness (Taylor et al., 1997; Weightman et al., 2008). In this study, sorghum kernel hardness was significantly related to protein content $(\mathrm{p}<0.001)$ and played an important role in ethanol yield $(\mathrm{p}<0.05)$. Test weight ranged from 0.74 to $0.77 \mathrm{~g} \mathrm{~cm}^{-3}$ (table 1), which is higher than U.S. No. 1 grade sorghum $\left(0.73 \mathrm{~g} \mathrm{~cm}^{-3}\right)$ (USDA, 2008). Sorghum samples treated with high irrigation levels had a higher test weight than those treated with low irrigation levels, which agrees with the results reported by Griess et al. (2010). True density of sorghum samples was not affected by irrigation level, which agrees with the research on sorghum (Griess et al., 2010). Kernel test weight was positively $(p<0.0001)$ correlated with starch contents but negatively $(\mathrm{p}<0.001)$ correlated with protein contents. Kaye et al. (2007) reported that kernel test weight was positively associated with grain yield. Ethanol yield was found to be greatly affected by kernel test weight $(p<0.0001)$, which agreed with the effects of irrigation level on ethanol yield.

Starch contents of sorghum samples grown under a low irrigation level were approximately $7.0 \%$ less than those under a high irrigation level (table 1). Griess et al. (2010) reported similar results: sorghum starch concentration under irrigated conditions was significantly higher than under dryland conditions. Figure 1 shows a strong linear relationship between total starch contents and ethanol yield $\left(\mathrm{R}^{2}=\right.$ $0.96, \mathrm{p}<0.0001)$, which agrees with the previous research reported by Wu et al. (2008), Lacerenza et al. (2008), and Yan et al. (2011). Starch content was not significantly correlated with fermentation efficiency $\left(\mathrm{R}^{2}=0.28\right)$. Protein contents ranged from $10.14 \%$ to $14.86 \%$; the lowest irrigation level resulted in the highest protein content, and the highest irrigation level resulted in the lowest protein content (table 1). It was expected that the grain protein content would be higher in the most drought conditions (Guttieri et al., 2000; Weightman et al., 2008). Daniel and Triboï (2002) reported that temperature increase as well as drought after anthesis induced an increase of the $\% \mathrm{~N}$ from $1.78 \%$ to $2.6 \%$ in wheat grain. Protein content was negatively correlated with ethanol yield $(\mathrm{p}<0.0001)$. The reason could be that grain kernels with higher protein content had lower accessibility of hydrolyzing enzymes to starch in the ground meal during the mashing and fermentation pro- cesses, and some small starch granules may be imbedded in the protein matrix (Wu et al., 2008). Samples with high starch content and low protein content are a better choice for fuel ethanol production. Higher starch means higher ethanol yield, better processing efficiency, and less leftover residues after fermentation (Wu et al., 2008). Starch content is positively correlated to grain yield (Griess et al., 2010), whereas protein content is negatively correlated to grain yield (Calderón-Chinchilla et al., 2008). Crude fat, fiber, and ash contents were in the ranges of $3.25 \%$ to $3.56 \%$, $1.43 \%$ to $1.73 \%$, and $1.38 \%$ to $1.72 \%$, respectively.

The SEM images showed that the starch granule size in samples with high irrigation levels were larger and had smoother surfaces than those of low irrigation level samples (fig. 2). The small starch granules were embedded in the protein matrix and may have remained ungelatinized during the cooking process; thus, they were not degradable into glucose for yeast fermentation by hydrolytic enzyme (Wang et al., 2008).

\section{Starch Thermal and Pasting Properties}

The transition temperatures $\left(T_{o}, T_{p}\right.$, and $\left.T_{c}\right)$ and enthalpies of gelatinization $\left(\Delta H_{g e l}\right)$ of the sorghum samples were determined by DSC. The $T_{o}, T_{p}$, and $T_{c}$ of the sorghum samples ranged from $71.4^{\circ} \mathrm{C}$ to $72.1{ }^{\circ} \mathrm{C}, 77.0^{\circ} \mathrm{C}$ to $77.4^{\circ} \mathrm{C}$, and $91.5^{\circ} \mathrm{C}$ to $92.5^{\circ} \mathrm{C}$, respectively. The DSC results showed that starch gelatinization onset, peak, and conclusion temperatures were similar among samples treated with high irrigation levels and samples treated with low irrigation levels (fig. 3a), so these qualities were not affected by irrigation levels. High transition temperatures usually result from a high degree of crystallinity, which makes the starch granules more resistant to gelatinization and requires more energy to initiate gelatinization (Barichello et al., 1990). Lower gelatinization temperature means easier enzymatic hydrolysis and higher fermentation efficiency ( $\mathrm{Wu}$ et al., 2008). The $H_{g e l}$ ranged from 7.01 to $9.82 \mathrm{~J} \mathrm{~g}^{-1}$. The $\Delta H_{\text {gel }}$ reflected the loss of double-helical order (Cooke and Gidley, 1992), and the variations in $\Delta H_{\text {gel }}$ represented differences in bonding forces between the double helices that form the amylopectin crystallites (McPherson and Jane, 1999). Previous studies indicate that amylose-lipid com-

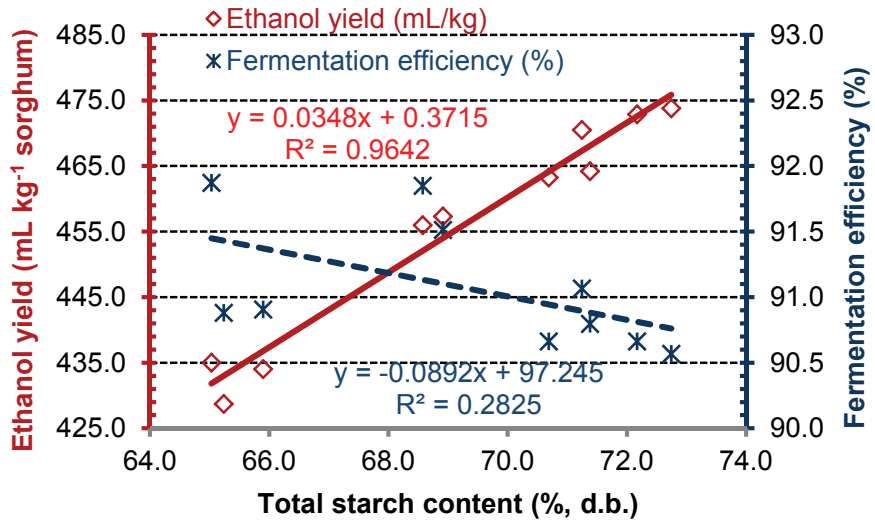

Figure 1. Relationship between starch content of sorghum samples, fermentation efficiency, and ethanol yield. 

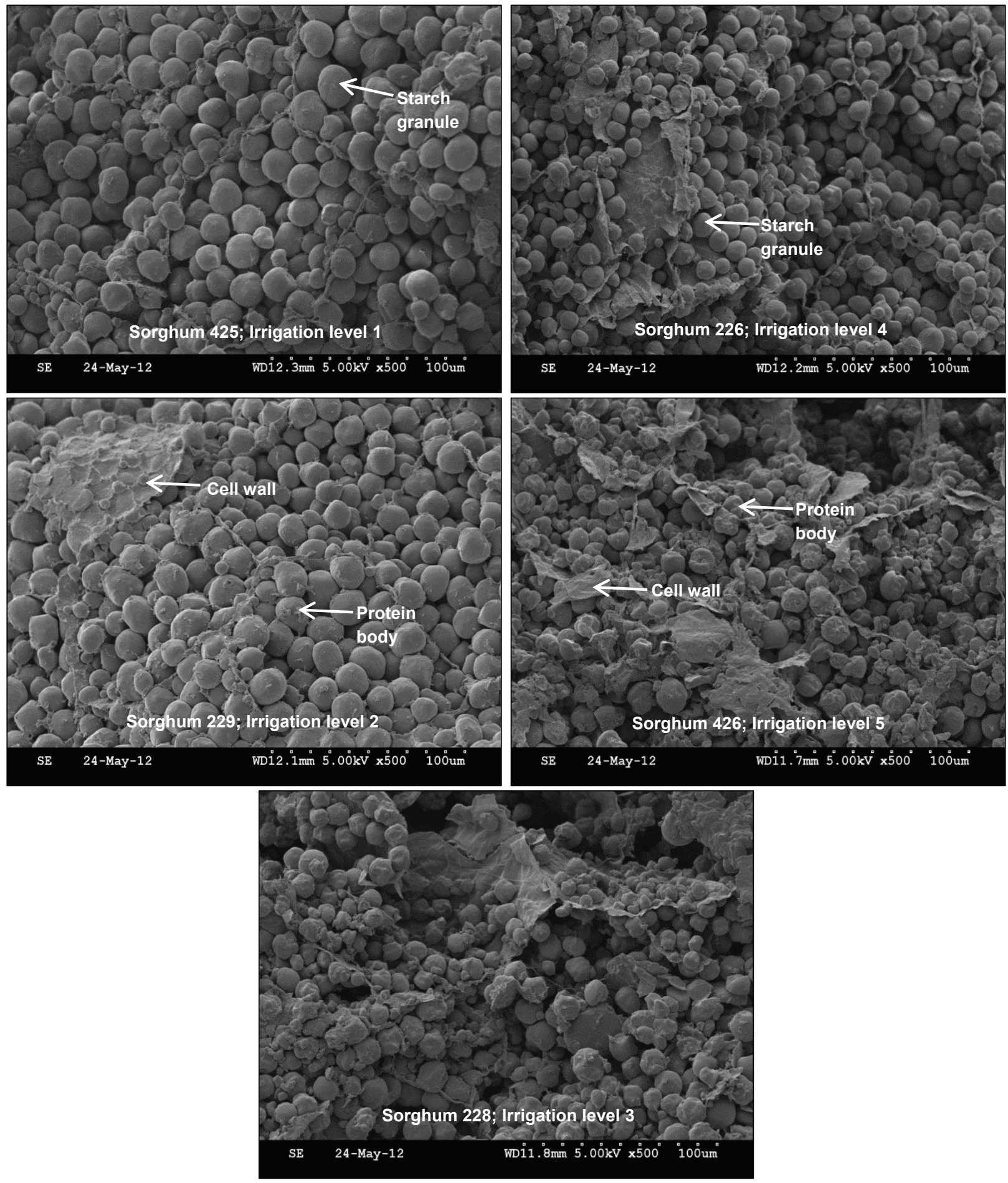

Figure 2. SEM images of starch granules and protein matrix in sorghum endosperm (irrigation level $1=$ highest, $5=$ lowest).

plexes may be formed during heating, and the percentage of amylose-lipid complexes was negatively correlated with fermentation efficiency (Le Bail et al., 1999; Ottenhof et al., 2005; Wu et al., 2007, 2008). In this study, the amyloselipid complex peak formed similarly for all samples (fig. $3 a)$, indicating that the amylose-lipid complex was not affected by irrigation level and did not play an important role in fermentation efficiency.

MVAG-U starch pasting profiles of sorghum samples treated with low irrigation levels showed a higher pasting temperature, lower peak pasting viscosity, and lower setback viscosity than those treated with high irrigation levels (fig. 3b). Taylor et al. (1997) reported similar results, noting that sorghums grown under supplementary irrigation had higher peak pasting viscosity and setback viscosity than those produced under rainfed conditions. The beginning of pasting temperature is defined by the initial increase in viscosity and is higher than the gelatinization onset temperature, meaning that the starch particles are gelatinized before the viscosity begins to increase (Liang and King, 2003). 


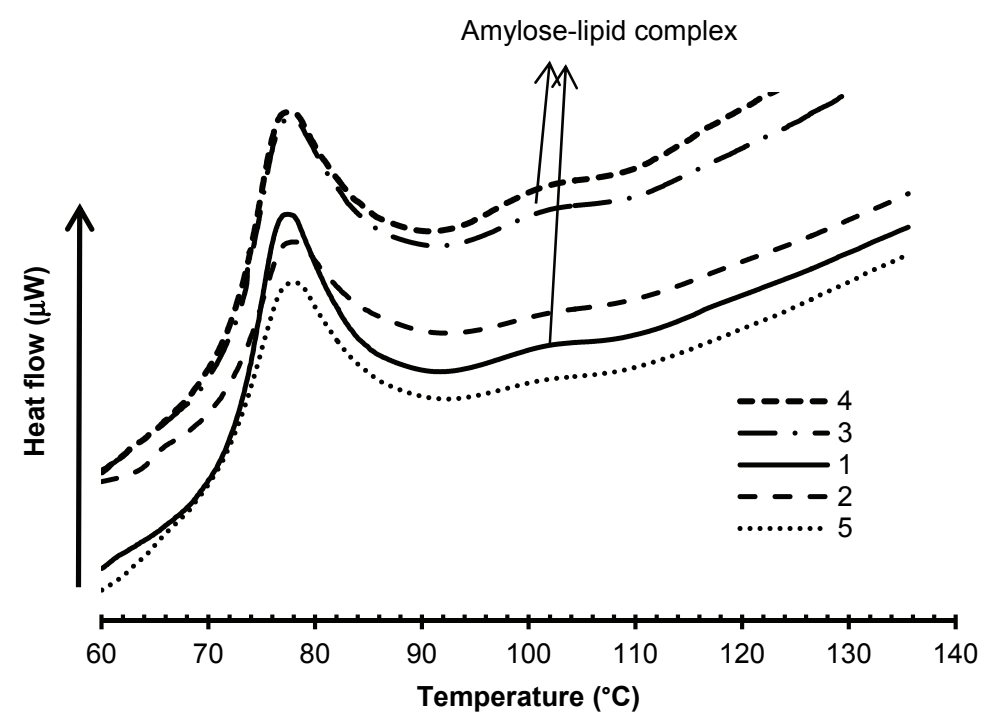

(a)

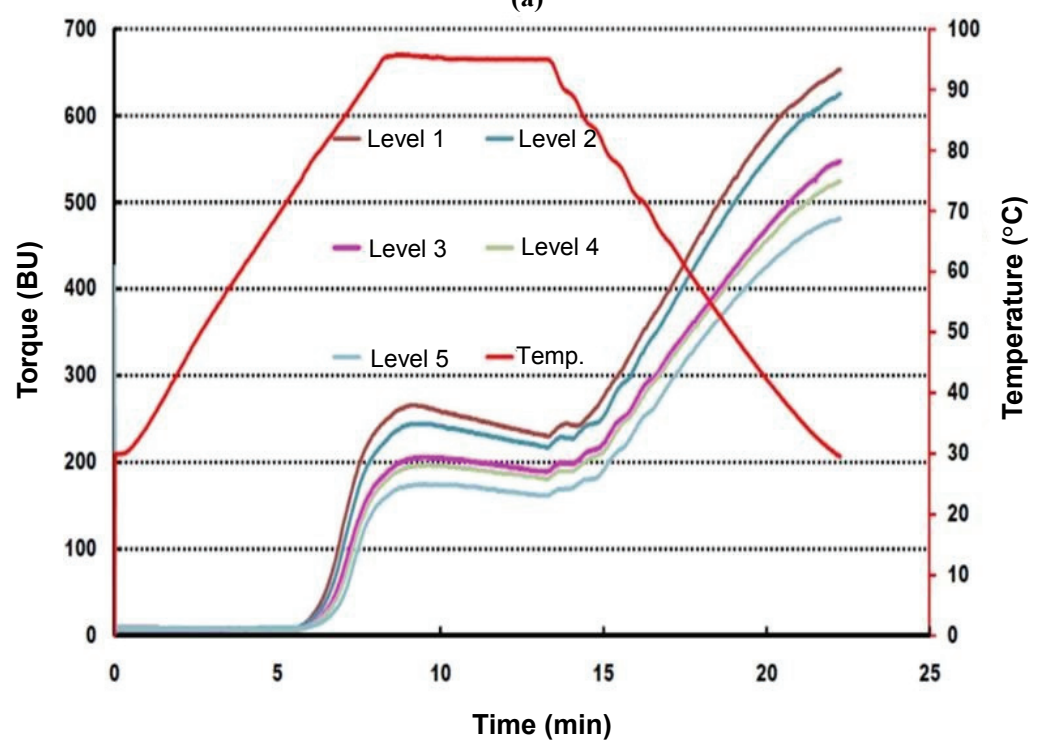

(b)

Figure 3. (a) Differential scanning calorimetry curves for sorghum samples from five different irrigation levels $(1=$ highest, $5=$ lowest $)$, and (b) starch pasting properties of sorghum samples from five different irrigation levels $(1=$ highest, $5=$ lowest $)$.

Setback is a process that occurs during cooling in which the starch molecules started to reorder and subsequently form a gel structure. A lower setback value is indicative of slower rates of starch retrogradation (Varavinit et al., 2003). Sorghum kernel hardness was negatively $(\mathrm{R}=-0.92, \mathrm{p}<$ $0.001)$ correlated with peak pasting viscosity, which agrees with the findings of Taylor et al. (1997).

\section{FERMENTATION EFFICIENCY AND ETHANOL YIELD}

Deficit irrigation level had a negative impact on ethanol yield. The sorghum with low irrigation yielded about $8.9 \%$ less ethanol (434.52 $\mathrm{mL}$ ethanol per $\mathrm{kg}$ sorghum) than samples with higher irrigation $(473.32 \mathrm{~mL}$ ethanol per kg sorghum) (table 1). The final fermentation efficiency (after a $72 \mathrm{~h}$ process) of sorghum samples ranged from $90.6 \%$ to $91.9 \%$. Monitoring the changes of conversion efficiency through the whole $72 \mathrm{~h}$ fermentation process demonstrated quite different dynamics in the process of reaching the final efficiency (fig. 4a). During the first $36 \mathrm{~h}$ of fermentation, sorghum samples from low irrigation treatments (low starch contents) had higher conversion efficiency than samples from high irrigation treatments (high starch contents) (fig. 4a). Samples with lower starch contents would have higher conversion efficiency if the same amount of yeast were put into the fermentation broth and the inoculated yeast converted sugar to ethanol at a similar rate. Another important factor that may affect the fermentation efficiency could be the FAN content. Initial FAN content was determined in this research and was significantly affected by irrigation level; FAN increased as the irrigation level decreased (table 1). A positive linear relationship $\left(\mathrm{R}^{2}=\right.$ 0.92) was found between the initial FAN contents and fer- 


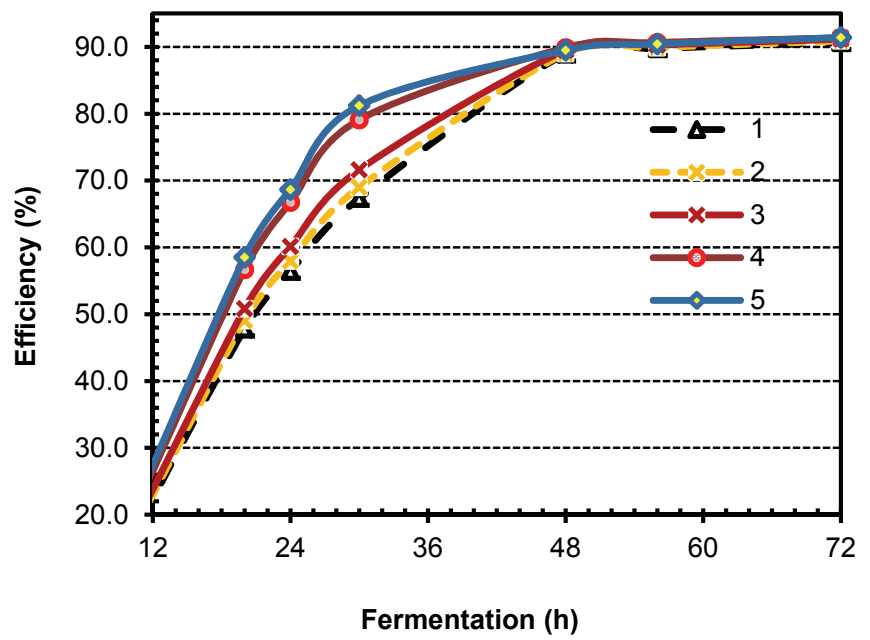

(a)

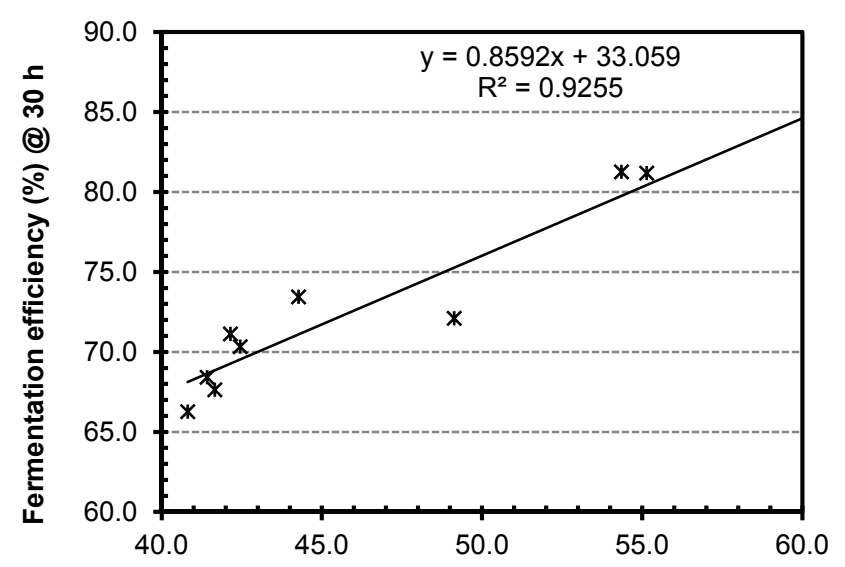

Free amino nitrogen (mg/L)

(b)

Figure 4. (a) Relationship between fermentation efficiency and fermentation time among sorghum samples from five different irrigation levels $\left(1\right.$ = highest, 5 = lowest), and (b) linear correlation between free amino nitrogen content $\left(\mathrm{mg} \mathrm{L}^{-1}\right)$ in original sorghum samples and fermentation efficiency after $30 \mathrm{~h}$ of fermentation.

mentation efficiency at $30 \mathrm{~h}$ of fermentation (fig. 4b), whereas no linear relationship was found between initial FAN contents and fermentation efficiency after $72 \mathrm{~h}$. Initial FAN content of samples is a crucial nutrient for yeast cell growth at the early stage of the fermentation process. The higher FAN contents resulted in a faster fermentation process, and this result was similar to several previous studies on sorghum samples (Wu et al., 2010; Yan et al., 2009, 2010, 2011) and wheat samples (Casey et al., 1984). Sufficient yeast nutrients had been put in the tested samples, and almost all the sugars were converted into ethanol; therefore, the final fermentation efficiency among samples was close.

\section{Chemical Composition OF DDGS}

Distillers dried grains with solubles (DDGS) is a byproduct of the ethanol production process and is a highnutrient feed for livestock. Protein, fat, and fiber are the main remaining nutrients used for livestock feed. The nutritional composition is critical to the ethanol industry because it determines the sale price of DDGS. Table 2 shows the major components of sorghum DDGS. Residual starch contents were all below $1 \%$ and were similar between high irrigation samples and the low irrigation samples. As discussed above, because sufficient yeast nutrients were added in the tested samples and almost all the sugars were converted into ethanol, the final conversion efficiencies were

Table 2. Chemical composition of distillers dried grain with solubles from sorghum samples (\% d.b.). ${ }^{[a]}$

\begin{tabular}{|c|c|c|c|c|c|}
\hline $\begin{array}{c}\text { Irrigation } \\
\text { Level } \\
(1=\text { High, } \\
5=\text { Low })\end{array}$ & $\begin{array}{c}\text { Starch } \\
(\% \text { d.b. })\end{array}$ & $\begin{array}{l}\text { Protein } \\
(\% \text { d.b. })\end{array}$ & $\begin{array}{c}\text { Fat } \\
(\% \text { d.b. })\end{array}$ & $\begin{array}{c}\text { Fiber } \\
\text { (\% d.b.) }\end{array}$ & $\begin{array}{c}\text { Ash } \\
(\% \text { d.b. })\end{array}$ \\
\hline 1 & $0.70 \mathrm{~b}$ & $33.04 \mathrm{~b}$ & $10.20 \mathrm{a}$ & $4.24 \mathrm{a}$ & $5.40 \mathrm{a}$ \\
\hline 2 & $0.74 \mathrm{ab}$ & $35.89 \mathrm{ab}$ & $10.08 \mathrm{a}$ & $4.90 \mathrm{a}$ & $5.16 \mathrm{a}$ \\
\hline 3 & $0.84 \mathrm{a}$ & $37.28 \mathrm{ab}$ & $9.52 \mathrm{a}$ & $4.14 \mathrm{a}$ & $5.08 \mathrm{a}$ \\
\hline 4 & $0.81 \mathrm{ab}$ & $39.82 \mathrm{a}$ & $9.37 \mathrm{a}$ & $4.03 \mathrm{a}$ & $4.91 \mathrm{a}$ \\
\hline 5 & $0.78 \mathrm{ab}$ & $39.47 \mathrm{a}$ & $8.76 \mathrm{a}$ & $3.76 \mathrm{a}$ & $4.96 \mathrm{a}$ \\
\hline $\begin{array}{l}\text { Means in } \\
\text { ly differe } \\
\text { significan } \\
\text { by "ab" } h \\
\text { "b." }\end{array}$ & $\begin{array}{l}\text { same col } \\
\leq 0.05 \text { ). } \\
\text { higher th } \\
\text { no signif }\end{array}$ & $\begin{array}{l}\text { follow } \\
\text { the same } \\
\text { means fo } \\
\text { nt differ }\end{array}$ & $\begin{array}{l}\text { y differ } \\
\text { umn, n } \\
\text { ved by } \\
\text { s with }\end{array}$ & $\begin{array}{l}\text { etters a } \\
\text { follov } \\
\text { and } m \\
\text { s follo }\end{array}$ & $\begin{array}{l}\text { gnificant- } \\
\text { py "a" are } \\
\text { followed } \\
\text { by "a" or }\end{array}$ \\
\hline
\end{tabular}


not significantly different. DDGS from samples with low irrigation levels had higher crude protein content. There were no differences in crude fat, fiber, and ash contents among all DDGS samples.

\section{CONCLUSION}

Irrigation had significant effects on grain physical properties, chemical composition, and ethanol yield. Irrigation level did not influence sorghum kernel weight and kernel size. Sorghum kernel hardness was significantly correlated with protein content and increased as irrigation level decreased. Starch contents in sorghum samples with deficit irrigation were lower than those with the high irrigation level and resulted in the lowest ethanol yield. The FAN content increased as irrigation level decreased, greatly affected fermentation efficiency at the early stage, and had a positive linear correlation with $30 \mathrm{~h}$ fermentation efficiency. The starch granule size was affected by irrigation level, and the starch-protein matrix in the grain may affect the fermentation efficiency. DDGS from samples with low irrigation levels had higher crude protein content.

\section{ACKNOWLEDGEMENTS}

This research was supported in part by the Ogallala Aquifer Program (a consortium of the USDA Agricultural Research Service, Kansas State University, Texas AgriLife Research, Texas AgriLife Extension Service, Texas Tech University, and West Texas A\&M University) and the Kansas Grain Sorghum Commission.

\section{REFERENCES}

AACC. 2000. Methods 55-10 and 76-13. In AACC International Approved Methods of Analysis. 10th ed. St. Paul, Minn.: AACC International.

AOAC. 1999. Methods 990.03, 920.39, and 942.05. In Official Methods of Analysis of AOAC International. 18th ed. Gaithersburg, Md.: AOAC International.

AOCS. 2006. Approved Procedure Ba 6a-05. ANKOM Technology Method 7. Urbana, Ill.: American Oil Chemists' Society.

Ayana, M. 2011. Deficit irrigation practices as alternative means of improving water use efficiencies in irrigated agriculture: Case study of maize crop at Arba Minch, Ethiopia. African J. Agric. Res. 6(2): 226-235.

Barichello, V., R. Y. Yada, R. H. Coffin, and D. W. Stanley. 1990. Low-temperature sweetening in susceptible and resistant potatoes: Starch structure and composition. J. Food Sci. 55(4): 1054-1057.

Bean, S. R., O. K. Chung, M. R. Tuinstra, J. F. Pedersen, and J. Erpelding. 2006. Evaluation of the single-kernel characterization system (SKCS) for measurement of sorghum grain attributes. Cereal Chem. 83(1): 108-113.

Calderón-Chinchilla, V. R., M. Hernández-Valle, S. C. Mason, and L. W. Rooney. 2008. Influencia del nitrógeno en la calidad del grano de sorgo en El Salvador (Influence of nitrogen on sorghum grain quality in El Salvador). Agron. Mesoamericana 19(1): 47-56.

Casey, G. P., C. A. Magnus, and W. M. Ingledew. 1984. Highgravity brewing: Effects of nutrition on yeast composition, fermentative ability, and alcohol production. Appl. and Environ. Microbiol. 48(3): 639-646.
Ciacci, C., L. Maiuri, N. Caporaso, C. Bucci, L. Del Giudice, D. Rita Massardo, P. Pontieri, N. Di Fonzo, S. R. Bean, B. Ioerger, and M. Londei. 2007. Celiac disease: In vitro and in vivo safety and palatability of wheat-free sorghum food products. Clinical Nutrition 26(6): 799-805.

Cooke, D., and M. J. Gidley. 1992. Loss of crystalline and molecular order during starch gelatinization: Origin of the enthalpic transition. Carbohydrate Res. 227: 103-112.

Daniel, C., and E. Triboï. 2002. Changes in wheat protein aggregation during grain development: Effects of temperatures and water stress. European J. Agron. 16(1): 1-12.

EBC. 1987. Free amino nitrogen-ninhydrin colorimentric method. In Analytic-EBC, E141-E142. 4th ed. Zurich, Switzerland: Braurei Getraenke Rundschau.

FAO. 2003. World agriculture: Towards 2015/2030. Available at: www.fao.org/docrep/005/Y4252E/y4252e00.htm. Accessed 16 April 2008. Rome, Italy: United Nations FAO.

Fereres, E., and M. A. Soriano. 2007. Deficit irrigation for reduced agricultural water use. J. Exp. Botany 58(2): 147-159.

Griess, J. K., S. C. Mason, D. S. Jackson, T. D. Galusha, M. Yaseen, and J. F. Pedersen. 2010. Environment and hybrid influences on food grade sorghum grain yield and hardness. Crop Sci. 50(4): 1480-1489.

Guttieri, M. J., R. Ahmad, J. C. Stark, and E. Souza. 2000. End-use quality of six hard red spring wheat cultivars at different irrigation levels. Crop Sci. 40(3): 631-635.

Kaye, N. M., S. C. Mason, D. S. Jackson, and T. D. Galusha. 2007. Crop rotation and soil amendment alters sorghum grain quality. Crop Sci. 47(2): 722-729.

Kirda, C. 2002. Deficit irrigation scheduling based on plant growth stages showing water stress tolerance In Water Report: Deficit Irrigation Practices. Available at: www.fao.org/docrep/004/ y3655e/y3655e00.htm. Rome, Italy: United Nations FAO.

Kirda, C., S., H. Topcu, A. C. Kaman, A. Ulger, M. Yazici, and M. R. D. Certin. 2005. Grain yield response and N-fertilizer recovery of maize under deficit irrigation. Field Crops Res. 93(2-3): 132-141.

Klocke, N. L., J. O. Payero, and J. P. Schneekloth. 2007. Long-term response of corn to limited irrigation and crop rotation. Trans. ASABE 50(6): 2117-2124.

Klocke, N. L., R. S. Currie, D. J. Tomsicek, and J. W. Koehn. 2011. Corn yield response to deficit irrigation. Trans. ASABE 54(3): 931-940.

Lacerenza, J. A., J. M. Martin, L. E. Talbert, S. P. Lanning, and M. J. Giroux. 2008. Relationship of ethanol yield to agronomic and seed quality characteristics of small grains. Cereal Chem. 85(3): 322-328.

Le Bail, P., H. Bizot, M. Ollivon, G. Keller, C. Bourgaux, and A. Buleon. 1999. Monitoring the crystallization of amylose-lipid complexes during maize starch melting by synchrotron x-ray diffraction. Biopolymers 50(1): 99-110.

Liang, X., and J. M. King. 2003. Pasting and crystalline property differences of commercial and isolate rice starch with added amino acids. J. Food Sci. 68(3): 832-838.

McPherson, A. E., and J. Jane. 1999. Comparison of waxy potato with other root and tuber starches. Carbohydrate Polymers 40(1): 57-60.

Miller, A. N., and M. J. Ottman. 2010. Irrigation frequency effects on growth and ethanol yield in sweet sorghum. J. Agron. 102(1): 60-70.

Ottenhof, M. A., S. E. Hill, and I. A. Farhat. 2005. Comparative study of the retrogradation of intermediate water content waxy maize, wheat, and potato starches. J. Agric. Food Chem. 53(3): 631-638.

Pandey, R. K., J. W. Maranville, and A. Admou. 2000. Deficit irrigation and nitrogen effects on maize in a Sahelian 
environment: I. Grain yield and yield components. Agric. Water Mgmt. 46(1): 1-13.

Pérez-Carrillo, E., and S. O. Serna-Saldívar. 2007. Effect of protease treatment before hydrolysis with $\alpha$-amylase on the rate of starch and protein hydrolysis of maize, whole sorghum, and decorticated sorghum. Cereal Chem. 84(6): 607-613.

Pomeranz, Y., C. R. Martin, D. D. Traylor, and F. S. Lai. 1984. Corn hardness determination. Cereal Chem. 61(2): 147-150.

Quiroga, D., Z. Fernandez-Haddad, and A. Iglesias. 2011. Crop yields response to water pressures in the Ebro basin in Spain: Risk and water policy implications. Hydrology and Earth System Sci. 15(2): 505-518.

Taylor, F. R. N., J. Dewar, J. Taylor, and R. F. von Ascheraden. 1997. Factors affecting the porridge-making quality of South African sorghums. J. Agric. Food Chem. 73(4): 464-470.

Thomas, K. C., S. H. Hynes, and W. M. Ingledew. 1996. Practical and theoretical considerations in the production of high concentrations of alcohol by fermentation. Proc. Biochem. 31(4): 321-331.

Tognetti, R., R. d'Andria, A. Lavini, and G. Morelli. 2006. The effect of deficit irrigation on crop yield and vegetative development of Olea europaea L. (cvs. Frantoio and Leccino). European J. Agron. 25(4): 356-364.

USDA. 2008. Grain Inspection Handbook: Book II, Chapter 9: Sorghum. Washington, D.C.: USDA Federal Grain Inspection Service. Available at: www.gipsa.usda.gov/publications/fgis/handbooks/graininsp/grbook2/sorghum.pdf.

USDA. 2011. Statistics of grain and feed. Washington, D.C.: USDA National Agricultural Statistics Service. Available at: www.nass. usda.gov/Publications/Ag_Statistics/2011/Chapter01.pdf.

Varavinit, S., S. Shobsngob, and V. Warunee. 2003. Effect of amylose content on gelatinization, retrogradation, and pasting properties of different cultivars of Thai rice. Starch/Stärke 55(9): 410-415.

Wang, D., S. R. Bean, J. McLaren, P. Seib, R. Madl, M. Tuinstra, Y. Shi, M. Lenz, X. Wu, and R. Zhao. 2008. Grain sorghum is a viable feedstock for ethanol production. J. Ind. Microbiol. Biotech. 35(5): 313-320.
Weightman, R. M., S. Millar, J. Alava, M. J. Foulkes, L. Fish, and J. W. Snape. 2008. Effects of drought and the presence of the 1BL/1RS translocation on grain vitreosity, hardness, and protein content in winter wheat. J. Cereal Sci. 47(3): 457-468.

$\mathrm{Wu}$, Y. V. 1989. Protein-rich residue from ethanolic fermentation of high-lysine, dent, waxy, and white corn varieties. Cereal Chem. 66(6): 506-509.

Wu, X., R. Zhao, D. Wang, S. R. Bean, P. A. Seib, M. R. Tuinstra, M. Campbell, and A. O. Brien. 2006. Effects of amylose, corn protein, and corn fiber contents on production of ethanol from starch-rich media. Cereal Chem. 83(5): 569-575.

Wu, X., R. Zhao, S. R. Bean, P. A. Seib, J. S. McLaren, R. L. Madl, M. Tuinstra, M. C. Lenz, and D. Wang. 2007. Factors impacting ethanol production from grain sorghum in the dry-grind process. Cereal Chem. 84(2): 130-136.

Wu, X., R. Zhao, L. Liu, S. R. Bean, P. A. Seib, J. McLaren, R. Madl, M. Tuinstra, M. Lenz, and D. Wang. 2008. Effects of growing location and irrigation on attributes and ethanol yields of selected grain sorghums. Cereal Chem. 85(4): 495-501.

Wu, X., B. Jampala, A. Robbins, D. Hays, S. Yan, F. Xu, W. Rooney, G. Peterson, Y. Shi, and D. Wang. 2010. Ethanol fermentation performance of grain sorghums (Sorghum bicolor) with modified endosperm matrices. J. Agric. Food Chem. 58(17): 9556-9562.

Yan, S., X. Wu, F. MacRitchie, and D. Wang. 2009. Germinationimproved ethanol fermentation performance of high-tannin sorghum in a laboratory dry-grind process. Cereal Chem. 86(6): 597-600.

Yan, S., X. Wu, J. Dahlberg, S. R. Bean, F. MacRitchie, J. D. Wilson, and D. Wang. 2010. Properties of field-sprouted sorghum and its performance in ethanol production. J. Cereal Sci. 51(3): 374-380.

Yan, S., X. Wu, S. R. Bean, J. F. Pedersen, T. Tesso, Y. R. Chen, and D. Wang. 2011. Evaluation of waxy grain sorghum for ethanol production. Cereal Chem. 88(6): 589-595.

Zhan, X., D. Wang, M. R. Tuistra, S. R. Bean, P. A. Seib, and X. S. Sun. 2003. Ethanol and lactic acid production as affected by sorghum genotype and location. Ind. Crops Prod. 18(3): 245255 . 